\title{
Excess Real Interest Rates and the Inflation Targeting Regime in Brazil: Monetary Policy Ineffectiveness and Rentiers' Interests
}

\author{
Fernando Ferrari Filho ${ }^{1} \&$ Marcelo Milan ${ }^{1 *}$ \\ ${ }^{1}$ Retired Professor of Economics at UFRGS and Researcher at CNPq, Brazil \\ ${ }^{2}$ Assistant Professor of Economics at UFRGS, Brazil \\ Correspondence: Fernando Ferrari Filho, Retired Professor of Economics at UFRGS and Researcher at CNPq, Brazil.
}

Received: September 25, 2018

doi:10.11114/aef.v5i6.3710
Accepted: October 9, $2018 \quad$ Available online: October 23, 2018

URL: https://doi.org/10.11114/aef.v5i6.3710

\begin{abstract}
Brazil has had, since the middle 1990s, one of the highest real interest rates in the world, yet not one of the lowest inflation rates. By the end of that decade, an inflation targeting regime (ITR) was introduced. Real interest rates have remained extremely high for international standards, while macroeconomic performance has been dismal on the same grounds. This article argues that these results can be explained by, among others reasons, pressures from the rentiers to frame monetary policy in a way to sustain very high interest earnings in a context where inflation is not very sensitive to monetary policy instruments. Under the ITR, the interest rate seems to have been kept above what would be required to maintain low inflation under normal conditions (even if one assumes a demand-pull inflation, which is not necessarily the case), with a potentially negative impact on growth and employment. This is interpreted as an indicator of monetary policy ineffectiveness. On the empirical ground, this article compares interest rate, inflation, unemployment, and real output growth for Brazil with both ITR and non-ITR countries selected by judgment sampling.
\end{abstract}

Keywords: real interest rate, inflation targeting regime, policy effectiveness, Brazilian economy, rentiers

JEL Classification: E31, E52, E58, O54.

\section{Introduction}

Since a major disinflation in the 1990s, Brazil has had very high nominal and real interest rates, for policy and business purposes, when compared to other countries with similar levels of income. The adoption of the inflation targeting regime (ITR) in 1999 does not seem to have changed this scenario. ${ }^{1}$ This raises the following questions: How monetary authorities have managed the monetary policy since then to keep such relatively high interest rates? What have been the main influences on the policymakers in operating the ITR? Are they just following the best-practice experiences proposed by monetary policy textbooks? Looking at the recent monetary history of Brazil, from July 1994 to January 1999, the monetary authorities have likely decided to maintain high nominal interest rates in order to attract capital flows to finance the current account deficits and to make an exchange rate anchor viable for inflationary expectations during the disinflation period. On the other hand, after the introduction of the ITR, the monetary policy has been operated broadly according to the most important issue highlighted by the New Macroeconomic Consensus (NMC) theoretical framework; that is, the interest rate tool aims at bringing the inflation rate to its target or, at least, to its tolerance intervals, with a minimum output and employment loss. Both policies seem to have favored rentier interests more than other economic interests in Brazil (the former are understood as the interests of those segments who derive most of their income from interest payments, mainly financial firms, but also financialized industrialists and wealthy households). This is because both policies failed at keeping inflation rates at comparatively low levels when the international experience is taken into account. At the same time, they may have contributed, not exclusively, to the

\footnotetext{
* The authors would like to thank two anonymous referees. They acknowledge all remaining errors and their responsibility.

${ }^{1}$ The average annual nominal and real policy interest rate, from 1999 to 2016, were $14.2 \%$ and $6.9 \%$, respectively. Authors' calculations based on statistical information from IPEADATA (2018).
} 
relatively poor macroeconomic performance in terms of income growth, whereas rentiers' earnings seem to be insured against losses by these very policies.

For instance, Brazil has had one of the highest nominal and real interest rates in the world, at the same time that the inflation rate, especially over the ITR period, has not been low when compared to other ITR and even non-ITR countries (as shown in section 3), in a context of pervasive decline in inflation rates around the world in the 1990s and 2000s (Ball, 2011: 431-433). Thus, for the years 1999-2016, the annual average inflation (measured by headline Consumer Price Index - CPI) rate was 6.8\% (above the upper limit of 6.5\%). In addition, high interest rates seem to have been highly correlated with poor macroeconomic performance: over the same period, the average real growth rate was $2.7 \%$ per year ${ }^{2}$, and there has been significant nominal budget deficits with high interest payments (Weisbrot $e t a l$, 2017).

Therefore, given this relatively poor macroeconomic performance, mainly regarding the goal of achieving low and stable inflation rates, it seems that monetary policy in Brazil has been quite ineffective in fulfilling its officially stated single objective. At the same time, since ineffectiveness here implies excessive real interest rates because the Brazilian Central Bank (BCB) maintains high nominal interest rates even when inflation does not fall when nominal interest rates are hiked, as expected by NMC models, it can contribute to income and wealth concentration to the extent that interest rates are tools of monetary policy and, at the same time, an important source of earnings for the rentiers. Indeed, there is a very strong and positive correlation between the Gini coefficient index and the interest rate in Brazil ( +0.87 for the period 1999-2016).

Hence, our main hypothesis is that this monetary policy ineffectiveness is explained by the pressures from the rentiers' interests on the $\mathrm{BCB}$ to obtain very high nominal and real interest rates, given the fact that inflation does not seem to be very sensitive to monetary policy instruments. We defend the argument that inflationary expectations by financial firms in the ITR have become a trap for monetary policy to the extent that they inform the decisions of the monetary authorities, thus disproportionately emphasizing the interests of the rentier fraction, mainly financial firms, but not only them, as suggested above. Thus, the interest rate has been kept above what would be necessary to maintain low inflation under normal conditions, but likely having negative impacts on output growth on the one hand, and concentrating income and wealth on the other. In order to evaluate our main hypothesis, the article analyzes and compares the monetary policy in Brazil with other countries, both the ones adopting the ITR and others not adopting. That is, this work evaluates the Brazilian monetary policy in the light of the international macroeconomic policy behavior regarding the interest-rate setting process and the likely consequences on the most important macroeconomic variables.

Besides this introduction, the article has four sections: In section two, we summarize the discussion about the ITR regime and the macroeconomic model implemented by the BCB to operate it. We also analyze the main results of the Brazilian experience with the ITR. In section three, we compare the Brazilian monetary policy and macroeconomic experience with other countries. In particular, the study compares international interest rates, inflation rates, real GDP growth rates, and unemployment rates using the World Bank (2018) database and information collected from central banks and other venues discussed in the appendix. In section four we interpret the results and provide an explanation based on our main hypothesis. Finally, section five summarizes and concludes the article.

\section{The BCB Macroeconomic Framework, the ITR, and the Brazilian Experience}

This section describes the macroeconomic model utilized by the BCB to adopt the ITR, broadly embedded in the NMC, points to some Post-Keynesian criticisms, and analyzes the Brazilian experience with that monetary policy rule.

\subsection{Theoretical Issues}

\subsubsection{The NMC Basic Theoretical Features}

The NMC model emerged in the beginning of the 1990s, and, since then, has become highly influential in terms of both macroeconomic thinking and macroeconomic, especially monetary, policy (Arestis \& Sawyer, 2008). The basic NMC model is characterized by three equations: the IS equation representing the demand side; the Phillips curve (PC) equation representing the supply side; and the monetary policy rule (MPR) equation" (Carlin \& Soskice, 2006). ${ }^{3}$ The MPR is the underpinning of the ITR. The rule fixes the central bank behavior under conditions of mostly demand shocks that deviate inflation from the target under rational expectations by key private players. In this approach, the instrument of monetary policy is the short-run nominal interest rate. When actual inflation rates converge to the

\footnotetext{
2 Authors' calculation based on statistical information from IPEADATA (2018).

${ }^{3}$ The last equation represents the Taylor Rule or the Inflation Targeting Rule. It is important to notice that there are different treatments for inflationary expectations in this model, and this has material consequences for our arguments below.
} 
inflation target established by the monetary authority (and, by divine coincidence, output is at the maximum sustainable level $)^{4}$, the policy rate is assumed to be on its natural level, balancing supply (PC) and demand (IS) in the goods and labor markets.

\subsubsection{Some Post-Keynesian Critiques}

Many Post-Keynesian authors, both at the theoretical and at the empirical level, have criticized the NMC. The review that follows below is not exhaustive and just highlights some important themes in the Post-Keynesian literature regarding this monetary policy framework. For instance, Setterfield (2006) claims that ITR is compatible with Post-Keynesian economics, but it must be modified to allow for distributive conflicts in determining inflation rates and the principle of effective demand in determining output. In this case, the central bank must also target output and employment. Lima \& Setterfield (2008) defend the use of ITR, but conditional upon a mix of policies. Santos (2011) reaches the same conclusion, but using a different theoretical framework to deal with an endogenous role for credibility in expectation formation rather than an exogenous one employed by Lima \& Setterfield (2008).

Drummond \& Porcile (2012) develop a Kaleckian model to cope with external sector imbalances, capital flows, and real exchange rates. The authors show that monetary regimes based exclusively on ITR are less stable than the ones considering both inflation and employment. Caldentey \& Vernengo (2013) argue that the ITR has its foundations in a closed economy setting, and is unlikely to work effectively in an open economy framework. In the latter, central banks pay attention to the external sector (capital flows, trade imbalances, foreign reserves and so on) and to exchange rates in their monetary policy decisions, and thus are not able to focus exclusively on inflation rates as required by the NMC. In an empirical study aligned with the claims of this study, Arestis \& Sawyer (2008) conclude that interest rates do not impact the inflation rates over the long run, but have damaging impacts over capital accumulation.

Epstein \& Yeldan (2009) bring forth several theoretical and empirical studies regarding the ITR. This monetary framework is considered flawed, mainly under conditions of frequent financial crises, and therefore the authors reject the ITR and exploit what they call 'socially useful policy alternatives' that best fit countries' macroeconomic experiences.

\subsection{The Brazilian Experience with the ITR}

\subsubsection{The Basic Setting}

Monetary authorities have adopted the ITR in Brazil since 1999, along with a target for primary fiscal budget surpluses as share of GDP, and a de jure but not de facto floating exchange rate regime (the so-called tripod). Focusing our attention on monetary policy alone, the BCB seems to have been following the theoretical framework that underpins the ITR strategy. According to Arestis, Ferrari Filho \& Paula (2011), the main theoretical features of the BCB macroeconomic model, closely based on the NMC view, can be summarized as follows:

(i) Price stability is monetary policy's primary long-term objective. In addition, the price stability goal may be accompanied by output stabilization so long as price stability is not at risk;

(ii) Fiscal policy is no longer viewed as a powerful macroeconomic instrument for stabilizing the economy. Hence, the economic authorities should adopt a fiscal target in terms of a primary budget surplus. This means that the Treasury has also been influenced by the orthodox view that it is necessary to sustain high primary budget surpluses in order to stabilize the debt-to-GDP ratio;

(iii) The level of economic activity fluctuates around a supply-side long-run equilibrium. This means that the level of effective demand does not play an independent role on the long-run level of economic activity;

(iv) Finally, considering that the Brazilian economy is open, with a history of external imbalances and payment crises, the exchange rate is of crucial importance, because it transmits external shocks to the interest and inflation rates. Given that, in the BCB macroeconomic framework it is assumed that the ITR may lead to a more stable currency, since it signals a clear commitment to price stability under a de jure floating exchange rate system.

The policy interest rate target is set by the Monetary Policy Committee (COPOM). The basic interest rate that the COPOM seeks to influence is the one derived from the Special System for Custody and Settlement of Government Bonds (Selic), an interest rate for overnight interbank loans, collateralized by those government bonds. The interest rate target is fixed for the period between the COPOM regular meetings (every 45 days). The President of the BCB, though, has the power to change the Selic interest rate target anytime between regular COPOM meetings. This is made possible by the way the COPOM decides about policy rates. It can introduce a monetary policy bias during its regular meetings, whereas the bias refers to easing or tightening monetary policy between meetings. Immediately after the COPOM

\footnotetext{
${ }^{4}$ Divine coincidence is a feature of the NMC in which the central bank closes the GDP gap by just bringing the inflation rate to its target (Blanchard \& Gali, 2005). See also Caldentey \& Vernengo (2013).
} 
meetings, the $\mathrm{BCB}$ publishes an Inflation Report, which provides specific information on economic conditions, as well as the COPOM's inflation forecasts upon which changes in the Selic interest rate are determined. The objective of this report is to inform the public and mainly the financial markets about the goals, design, and implementation of monetary policy.

\subsubsection{ITR in Brazil: Performance and Theoretical Challenges}

Table 1 below shows the point targets, the tolerance intervals, inflation rates, measured by the effective headline CPI (IPCA in Brazil), annual interest rates (nominal and real) and annual growth rates from 1999 to 2016. By examining Table 1, it is noticeable that over the 1999-2016 intervals, the tolerance intervals were missed for three years: 2001, 2002, 2003 and 2015, noticeably by a substantial margin in 2002 and 2015, while in 2004 the inflation target was only met after it was expediently raised by mid-2003. So, inflation was over the upper limit for 4 out of 18 years (excluding 2004). Moreover, the inflation rates were relatively high, for international standards: once again, for 1999-2016, the average inflation rate was $6.8 \%$ per year. It seems therefore that the ITR in Brazil has not been completely successful over the 18 years of its implementation, mainly because it has not been effective in maintaining a low and stable inflation at a low cost in terms of output and employment, as assumed by the NMC and shown by the international comparison in the next section.

Table 1. Inflation Targets and Inflation Rates (IPCA), Selic and Growth Rates, \%, from 1999 to 2016

\begin{tabular}{c|c|c|c|c|c|c}
\hline Year & $\begin{array}{c}\text { Point } \\
\text { Targets }\end{array}$ & $\begin{array}{c}\text { Tolerance } \\
\text { Intervals }\end{array}$ & IPCA & $\begin{array}{c}\text { Annual Interest } \\
\text { Rate (Selic) }^{\mathbf{1}}\end{array}$ & $\begin{array}{c}\text { Annual Real } \\
\text { Interest Rate }^{2}\end{array}$ & $\begin{array}{c}\text { Annual Growth } \\
\text { Rate }^{-}\end{array}$ \\
\hline 1999 & 8 & 6 to 10 & 8.94 & 19.0 & 9.2 & 0.3 \\
\hline 2000 & 6 & 4 to 8 & 5.97 & 15.75 & 9.2 & 4.3 \\
\hline 2001 & 4 & 2 to 6 & 7.67 & 19.0 & 8.5 & 1.3 \\
\hline 2002 & 3.5 & 1.5 to 6.5 & 12.53 & 25.0 & 11.1 & 3.1 \\
\hline 2003 & 4 & 1.5 to 6.5 & 9.3 & 16.5 & 6.6 & 1.3 \\
\hline $2004^{3}$ & 5.5 & 3.5 to 8 & 7.6 & 17.75 & 9.4 & 5.7 \\
\hline 2005 & 4.5 & 2.5 to 7.5 & 5.69 & 18.0 & 9.8 & 4.0 \\
\hline 2006 & 4.5 & 2.5 to 7.5 & 3.14 & 13.25 & 6.5 & 6.0 \\
\hline 2007 & 4.5 & 2.5 to 6.5 & 4.46 & 11.25 & 7.4 & 5.0 \\
\hline 2008 & 4.5 & 2.5 to 6.5 & 5.9 & 13.75 & 4.3 & -0.2 \\
\hline 2009 & 4.5 & 2.5 to 6.5 & 4.31 & 8.75 & 4.6 & 7.6 \\
\hline 2010 & 4.5 & 2.5 to 6.5 & 5.91 & 10.75 & 4.2 & 3.9 \\
\hline 2011 & 4.5 & 2.5 to 6.5 & 6.5 & 11.0 & 1.3 & 1.8 \\
\hline 2012 & 4.5 & 2.5 to 6.5 & 5.84 & 7.25 & 3.9 & 2.7 \\
\hline 2013 & 4.5 & 2.5 to 6.5 & 5.91 & 10.0 & 5.0 & 0.1 \\
\hline 2014 & 4.5 & 2.5 to 6.5 & 6.41 & 11.75 & 3.2 & -3.8 \\
\hline 2015 & 4.5 & 2.5 to 6.5 & 10.67 & 14.25 & 7.0 & -3.6 \\
\hline 2016 & 4.5 & 2.5 to 6.5 & 6.29 & 13.75 & & \\
\hline
\end{tabular}

Source: Author's elaboration based on BCB (2018).

Note: (1) End of period; (2) Annual Interest Rate (Selic)/IPCA; and (3) The original inflation target for 2004 was 3.75\% (with a tolerance interval of $2.5 \%$ ). Subsequently, the BCB changed the inflation target to $5.5 \%$ and kept the $\pm 2.5 \%$ of tolerance interval.

As Table 1 shows, ex post real interest rates have gradually fallen since 2008, after the international financial crisis (IFC), mainly by slowly falling inflation (the exception was in 2015) and nominal interest rates (the exceptions were in 2014 and 2015). They were very high during the first years of the ITR, and reached, comparatively to this first period alone, less high levels from the second half of the period on. Actually, in the spirit of Ball \& Sheridan (2003), nominal interest and inflation rates started declining before ITR, but have remained relatively high in comparison with other countries that also experienced falling prices and interest rates. It is clear that, for the entire interval, inflation rates have been more or less constant in terms of trends, despite a period of fast rising prices from 1999 to 2003 and 2015, but with a considerable volatility. This trend suggests that inflation rates have not been very sensitive to interest rates, since prices increased fast when nominal interest rates were skyrocket high, instead of dropping as predicted by the NMC, and did not increase when nominal interest rates fell from very high to less high levels. It is important not to confuse levels with changes. A very high interest rate may fall and still be high in absolute terms. And the average will still capture the period of very high and less high interest rates.

For the entire period considered, there does not seem to be an inverse relationship between nominal interest rates, the only legitimate policy instrument under the ITR, and headline inflation rates, the ultimate goal of monetary policy for NMC-type central banks. 
Given that, a question arises: what are the relevant macroeconomic relationships between actual inflation rates and interest rates? Theoretically, if ITR central banks are forward-looking, as the rational expectations assumption in the NMC would require, this means that the appropriate inverse relationship is the one between current nominal interest rates and future or expected inflation rates, since future inflation rates cannot be known for sure. Central banks then use these expectations as their targets, assuming that they, eventually, 'rationally' converge to actual rates if the model works.

These perspectives claim that higher interest rates increase the costs of production of indebted firms (there is also a markup over interest costs, not only labor and other material costs) and thus higher interest rates are associated with higher inflation rates, not lower. Moreover, higher interest rates are passed through the prices set by net indebted nonfinancial firms. If the later behave like that, then monetary policy cannot work as supposed in the NMC, as found by Arestis \& Sawyer (2008). ITR would be a self-defeating policy. But if this is the case, Brazil would have to display one of the highest leverage ratios in the world in order to justify the relatively high inflation rates. So, we discard this cost-push source of inflation as likely to explain the Brazilian experience.

According to the NMC, when expected inflation rates go up, ITR central banks increase interest rates to reduced aggregate demand (shift the IS curve down) and bring actual future inflation rates down, even if currently prices have not yet increased. However, if aggregate demand is interest-elastic, and prices are responsive to demand changes, tight monetary policies must cause actual inflation rates to go down in the near or distant future. This implies that monetary policy has lags, and forward-looking central banks must adjust interest rates today to affect actual inflation (or any other target) in the future. In other words, if one assumes lags in the implementation of monetary policy, as suggested by Carlin \& Soskice (2006), even though the authors do not deal with expectations per se, central banks must consider future ex post real interest rates that are compatible with current expectations about future inflation rates. As it is argued in the next section, this creates potentially a trap.

Nonetheless, the positive relationship between interest rates and inflation appears also in Brazil when lags are introduced (Ferrari Filho \& Milan, 2018). Thus, lagging interest rates by one year (one-year lag between nominal interest rates and actual inflation that in this case could become a proxy for expected inflation) reduces the R-squared, but does not cause the positive relationship to disappear. The same is true for a 2-year lag. These results go against the ITR or any other monetary policy that uses the interest rate to target changes in prices in Brazil, unless the country has some anomalies in which inflationary inertia requires more than 2 years for higher interest rates to work its effects on actual future inflation out via credit-financed spending. It is more likely that monetary policy under the ITR in Brazil is ineffective, as already suggested by other Post-Keynesian empirical studies, and excessive real interest rates are a plausible consequence of such ineffectiveness, since nominal interest rates will go up, following the NMC, but ex post inflation rates will not fall as much. That is, regardless of expectations about future inflation, higher nominal interests today must objectively reduce credit-financed spending, and reduce aggregate demand, output, and prices in the future. If inflation rates two years from now are positively correlated with current interest rates, this means that the inflation rate is not very sensitive to the monetary policy instrument in Brazil. ${ }^{5}$

A hypothetical defense of the NMC in face of this anomaly, which of course by no means is the argument advanced in this article, could be that interest rates in Brazil, despite being among the highest ones in the world, as it is shown in the next section, are still not high enough and consequently monetary policy is not credible to bring inflation down (BCB is dovish) according to financial market participants in particular and rentiers in general. So, the anomaly would not be the high interest rates, but the macroeconomic fundamentals that could cause agents (financial institutions) to expect higher inflation rates and hence lower the ex ante real interest rates in the future. That is, actual inflation rates would be high because interest rates have been kept not too high, but too low and therefore not compatible with expected inflation

\footnotetext{
${ }^{5}$ One can advance several other possible explanations, besides the ones discussed below in which supply factors are the single most important factor for inflationary dynamics in Brazil, with the result that demand-side monetary policies are ineffective. Just to mention a few, one is that the market interest rates are so absurdly high in Brazil that spending is not very sensitive to changes in policy interest rates. Another is that inertial inflation, a major feature of the hyperinflation years, has not been completely eliminated, and inflation grows today because it grew in the past (inflationary culture of Brazilian firms). A third one is the presence of oligopolies that adjust their markups when sales decline to maintain their revenues. Thus, interest rates reduce credit-financed sales and merchants' margins, but oligopolies are able to raise their prices (and inflation). A fourth motive is that the transmission mechanisms of monetary policy are clogged in Brazil because of the high inflation period. If this is the case though, monetary authorities should unclog the mechanisms before keeping interest rates above "civilized" levels. It does not seem that high interest rates will unblock the transmission mechanisms by any means.
} 
rates based on 'sound' macroeconomic trends determined by the financial sector and rentiers NMC models. Inflation rates would in this case be apparently generated exclusively by rational expectations process regarding aggregate demand dynamics, properly interpreted through NMC lenses, since model-consistency is a hallmark of rational expectations. In this view, the "natural" interest rate is the only rate consistent with the convergence between expected and actual inflation rates. The policy instrument, when set at the proper or "natural" level, allows expected or ex ante inflation to be consistent with the 'correct' actual or ex post inflation. Expectations are therefore all that matter for inflationary dynamics, and only "natural" rates can tame them. If inflation is high, nominal interest rates are not high enough.

Yet, if one assumes lags in monetary policy, and mainly variable lags, they could potentially decouple actual inflation rates from expected inflation rates, invalidating the rational expectations assumption behind the NMC. One solution to save the face of the latter would be to assume that lags are variable but on average can be estimated and incorporated into the framework of rational expectations (agents include the variable lags in their expectation formation process). This would make expectations more uncertain, though. Yet, this does not make any sense considering the Brazilian experience.

Another problem with estimating an ex ante real interest rates in Brazil instead of using nominal interest rates to evaluate policy effectiveness is that the survey of 'market' expectations used by the BCB has its sample made up mostly of financial firms, excluding important prices makers from the process to the best of our knowledge. According to the BCB (2016: 8, italics and bold added), currently the sample of institutions inquired in the expectation system implemented with the ITR contains 130 firms, "mostly banks, wealth managers, brokers and depositories, besides consultant firms and other nonfinancial firms." So, the BCB relies, for setting the policy rate, in its own official words, mostly on the inflationary expectations of the financial firms that have vested interests in the very rate at which their financial wealth grows.

The relatively poor ITR performance in Brazil, with high interest rate not able to ensure lower and stable inflation rates at least close to the international averages, is also backed by other studies. For example, Modenesi \& Araújo (2013), based on an econometric analysis of the monetary policy transmission mechanism in Brazil, endorses our claim that inflation is not directly sensitive to the interest rate. In other words, a rise in the policy interest rate generates small, if any, benefits in terms of a fall in the inflation rate. Also, the literature that estimates the reaction function of the $\mathrm{BCB}$ after the adoption of ITR shows that the BCB reaction to inflation has been asymmetric: (i) increases in the actual inflation rates generate a more than proportional reaction by the $\mathrm{BCB}$ in raising interest rates; and (ii) the $\mathrm{BCB}$ reduces the policy rates very slowly when there is a fall in the actual inflation rate and/or a sharp reduction in the output growth. This is compatible with an inflation expectation trap, since the result of this asymmetric behavior is a relatively high real interest rate. Libanio (2010) argues that the way that monetary policy has been conducted in Brazil under the ITR, with a floating exchange regime and a liberalized financial account, brings about an upward bias in interest rates, which harms aggregate demand and, as a consequence, affects the economic growth negatively. Using a VAR model, he shows evidence that monetary policy has been pro-cyclical and asymmetric in Brazil.

Considering that high interest rates have not affected the actual inflation rate as predicted by the NMC, but are nonetheless maintained at relatively high levels by the BCB, other studies have found different answers for this behavior. According to Arestis, Ferrari Filho \& Paula (2011), the interest rate policy aims at stabilizing the exchange rate volatility, given that the later indirectly affects the GDP deflator via wholesale prices, which by its turn affects some administered prices and retail prices. As administered prices change, the headline consumer inflation is also affected, given its composition. Indeed, periods of sustained currency appreciation have resulted in a moderation in the rate of inflation, with a time lag, while periods of currency depreciation have affected domestic prices positively via the exchange rate pass-through mechanism. Thus, observing the inflation performance from 1999 to 2016, it is possible to conclude that inflation targets were only met, within the tolerance intervals, when international financial and liquidity conditions allowed it. In other words, ITR was less ineffective when the currency appreciation caused by capital inflows prevented inflation from rising. The authors do not explain, however, why the interest rates must be so high in order to achieve this outcome of currency appreciation. Also, a major consequence of this type of indirect control has been the deindustrialization of the Brazilian economy, contributing to reduce economic dynamism and future output (Marconi \& Rocha, 2012).

As a major challenge to the demand-pull forces embedded in expectations that back the ITR, in Brazil inflation has likely been determined by two factors: (i) cost-push, explained either by negative or positive supply shocks such as movements in the exchange rate, changes in the international prices of commodities, labor costs, and so on; and (ii) by partial inertia due to the indexation of the administered prices and minimum wages. In this context, considering that an increase in prices is not caused by a situation of excess demand, the monetary policy of high nominal interest rates is ineffective to reduce and stabilize inflation, causing the ex post real interest rate to remain relatively high. Thus, Borio 
\& Filardo (2007), based on empirical evidence, argue that inflation is mostly imported for less developed countries (LDC) under globalization, backing the first set of factors. Summa \& Serrano (2015) provide additional evidence to support the importance of both factors. Therefore, it should be emphasized that, despite a positive correlation between nominal interest rates and current and future inflation rates, it is not our claim that rentiers' expectations cause inflation rates. This would be a spurious causation relation. Rentiers' expectations cause the interest rates to be abnormally high, and mostly cost-push factors cause the inflation to remain at relatively high levels and fluctuate over time. Since inflation is not caused by excess demand, stubbornly high real interest rates will not have much impact on prices, so both will be positively correlated.

If monetary policy has likely been ineffective in maintaining a low and stable inflation in Brazil, are there other macroeconomic costs of maintaining high interest rates, besides the likely income concentration?

So, it seems that, at first, high interest rates may cause weak economic activity, with a contemporaneous negative relationship between them, but the slow growth rates do not impinge on prices. From 1999 to 2016, real GDP has followed a stop-and-go pattern and its average annual growth rate hovered around $2.7 \%$, significantly below the average growth rate of other emerging countries that have adopted an ITR (Arestis, Ferrari Filho \& Paula, 2011; Ferrari Filho \& Schifino, 2010). Thus, high real interest rates might cause a constraint on economic growth, through the cost of credit (loan rates) and entrepreneurs' poor expectations, with a heavier impact on output rather than prices. On the other hand, high interest rates increase public debt, which has been composed mainly of indexed bonds or short-term fixed-rate bonds (Weisbrot et al., 2017). So, the average income drops, and the interest income increases its share on output, highlighting the nature of an income transfer. Figure 1, below, shows the relationship between real interest rate and economic growth:

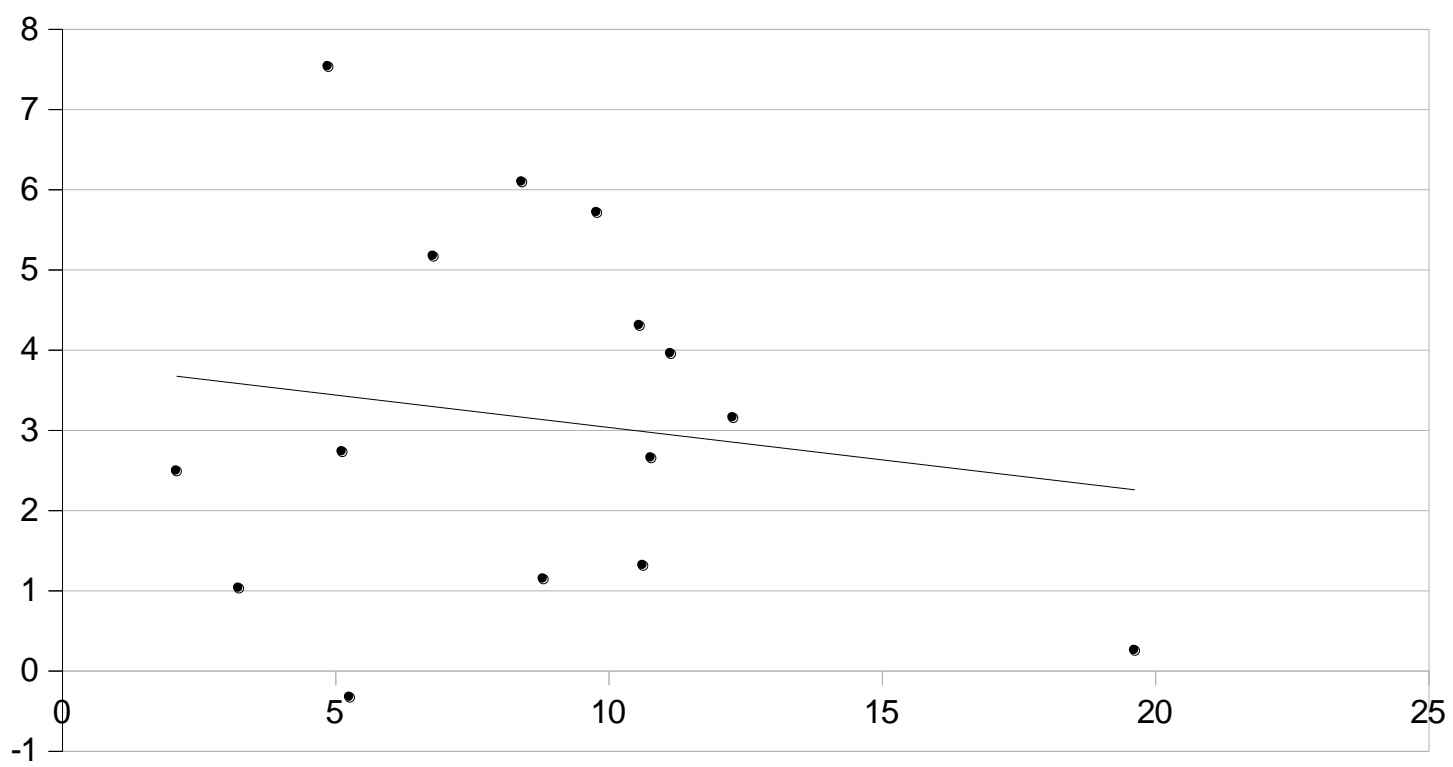

Figure 1. Real Interest Rates (horizontal axis) and Real Output Growth (vertical axis) in Brazil, \%, for 1999-2016 Source: Elaborated by the authors using data from BCB (2018).

In concluding this section, we can briefly summarize it as follows. First, monetary policy and high interest rates under ITR, following broadly the basic dictates of the NMC, have not been effective at reducing and stabilizing inflation in Brazil. This is because the main causes of the Brazilian inflation rate seem to be related to cost-push factors, such as movements in the exchange rate, changes in the international prices of commodities, distributive conflicts etc., and by partial inertia due to the indexation of the administered prices. Second, high interest rates might have contributed to the poor performance of the GDP growth rate and to many other problems, including the nominal fiscal deficits and a higher public debt. If the latter is true, monetary policy is mostly a policy of income transfers to rentiers, who inform the expectations used by the $\mathrm{BCB}$ to set the interest rates.

\section{Understanding the Brazilian Experience in the Light of the International Trends}

\subsection{Method of Inquiry}

Many empirical studies regarding ITR adopt a "before and after" approach, assessing the macroeconomic performance regarding inflation for two periods, one before the adoption of the ITR and another after (Ball \& Sheridan, 2003). Ball \& Sheridan (2003) use non-adopting countries as a control group, and conclude that ITR is not relevant to achieve 
lower inflation rates, since non-inflation targets have equally obtained such results. As mentioned before, inflation rates have been falling around the world (Ball, 2011). This method has been widely used and will not be replicated here. The method used in this work uses three groups for comparison with Brazil, so that we can have a criterion for assessing the level of nominal and real interest rates: (i) the fully fledged inflation targets, ${ }^{6}$ without a control group, but also paying attention to countries with a past of hyperinflation and domestic debt default or restructuring for a better comparison of interest rate levels; (ii) the BRICS countries; and (iii) countries assumed to have abnormally high nominal interest rates. It should be noticed that international comparisons of real interest rates have been relatively common in the orthodox economic literature (Barro \& Sala-I-Martin, 1990), but less so in the heterodox field.

The first group is a natural choice. However, since ITR countries have different experiences with inflation and interest rate management, the period covered cannot be the same, and the study adjusts for that by using averages and other descriptive statistics as comparative tools. In the sample, considering the year of formal or legal adoption, there are only eight countries more experienced than Brazil regarding ITR. Therefore, learning to manage inflation under the ITR should not be an excuse for keeping high interest rates. Subdivisions in terms of years of adoption are possible, but not carried out in this study.

The second group is perhaps arbitrary. Yet, all members are LDC with a relatively good macroeconomic performance before the IFC and Great Recession of 2007-2009. In this group, two countries are fully fledged ITR (Brazil and South Africa). The third group was considered for the following reason. Hanke (2014) modified the traditional misery index by including the interest rate and real GDP per capita growth in the estimation. The author then creates a rank of countries, highlighting the most important contributing factor to the misery. Brazil figures among the worst countries ranked, and the major contributing factor is, as expected, the abnormally high interest rates. The top-five countries for which interest rates are the most important contributing factor to the economic misery were considered in the third group (Jamaica, Brazil, Nicaragua, Honduras, and Costa Rica).

Overall, countries have different macroeconomic goals and strategies and this should be considered when doing international comparisons. For instance, Central America countries, considering the central bank statements on their websites, are more concerned with external balance and international reserves than with interest rates and inflation. On another matter, Colombia uses other instruments besides interest rates to control inflation. This raises an important point regarding the anti-inflationary policies: monetary policy is not necessarily the only game in town, because inflation is not necessarily always and everywhere a monetary phenomenon. Also, Russia has a target for inflation, but it is not a full-fledged ITR. India establishes price stability in terms of a target, but explicitly assumes that economic growth matters. Jamaica has a similar approach. Costa Rica has moved to ITR, but has not concluded the transition. And so on and so forth.

Thus, information about headline CPI inflation, short-term policy interest rates, output, and employment was collected. More detailed information about the empirical methodology may be obtained upon request. For the sake of measuring effectiveness, excess real interest rates are any existing positive real interest rate for the time considered. So, the higher the real interest rate, the more ineffective is the policy. The most effective policy is the one with zero real interest rate.

\footnotetext{
${ }^{6}$ According to Hammond (2012), the 27 fully-fledged inflation targets, as of start of 2012, were (with date of full adoption in parenthesis - the formal date of adoption was employed in our empirical analysis): Armenia (January 2006), Australia (June 1993), Brazil (June 1999), Canada (February 1991), Chile (September 1999), Colombia (October 1999), Czech Republic (December 1997), Ghana (May 2007), Guatemala (2005), Hungary (June 2001), Iceland (March 2001), Indonesia (July 2005), Israel (June 1997), Mexico (2001), New Zealand (December 1989), Norway (March 2001), Peru (January 2002), Philippines (January 2002), Poland (1998), Romania (August 2005), Serbia (January 2009), South Africa (February 2000), South Korea (April 1998), Sweden (1995), Thailand (May 2000), Turkey (January 2006) and United Kingdom (October 1992). Some specific remarks are worth making, given that they reinforce our argument in this article about ITR. For instance, in New Zealand, the average annual inflation rate before the introduction of the OCR (official cash rate) as the key policy rate (1990-1998) was 2.35\%, and after (1999-2013) it was 2.38\%. This suggests again that interest rates may not necessarily be the most efficient instrument for controlling inflation in capitalist economies under an ITR, and that the regime itself may not be relevant for reducing and stabilizing inflation. Similarly, Turkey switched its key policy interest rate to the 1-week repo rate in 2010 . Before that, the rate used was the overnight rate. One of the arguments used in favor of the change was that the central bank is a net lender, not borrower. In this case, until 2009 there was a net positive payment flow to the central bank. When the central bank switched to the 1 -week repo rate, the flows were reverted. Given that in the repo market the central bank is a net lender, and since no borrowing rates are available, this means that banks now pay net positive flows to other money market institutions. So, the policy switch can be seem as a way to increase rentiers' earnings.
} 
In the NMC, there is an optimum nominal interest rate fully compatible with achieving the ITR. Since the nominal interest rate set by central bank is only the lowest short-term interest rate, a zero real interest rate at the central bank still represents a positive real interest rate in the financial sector, assuming a mark-up or spread (Rousseas, 1985). This zero real policy interest rate is in the spirit of the "Smithin Rule" (Asensio, 2012; Smithin, 2007).

\subsection{International Comparison: Descriptive Statistics}

Regarding inflation, according to Figure 2, in comparison with the other 26 full ITR countries (footnote 6), Brazil (big black circle) ranks $23^{\text {rd }}$ regarding average, median, and minimum annual inflation (meaning in that case that other 22 countries had lower average, median, and minimum inflation rates during their ITR period). It has the second highest maximum inflation rate for the period considered, and ranks $21^{\text {st }}$ regarding inflation volatility (meaning that other 20 countries had lower standard deviations for the headline CPI inflation). So, using the international experience with ITR, Brazil has not managed to achieve low and stable inflation. This international comparison may not be the only or best one criterion, but it is one used widely by the literature and adopted in this work to evaluate monetary policy in Brazil. This means that the ITR in Brazil, to the extent that it is a valid method for stabilizing prices, and Ball \& Sheridan (2003) suggest it is not, has not been very successful in achieving low and stable inflation in comparison with other countries adopting ITR, and not only considering the evolution of the regime in Brazil, as discussed in the previous section.

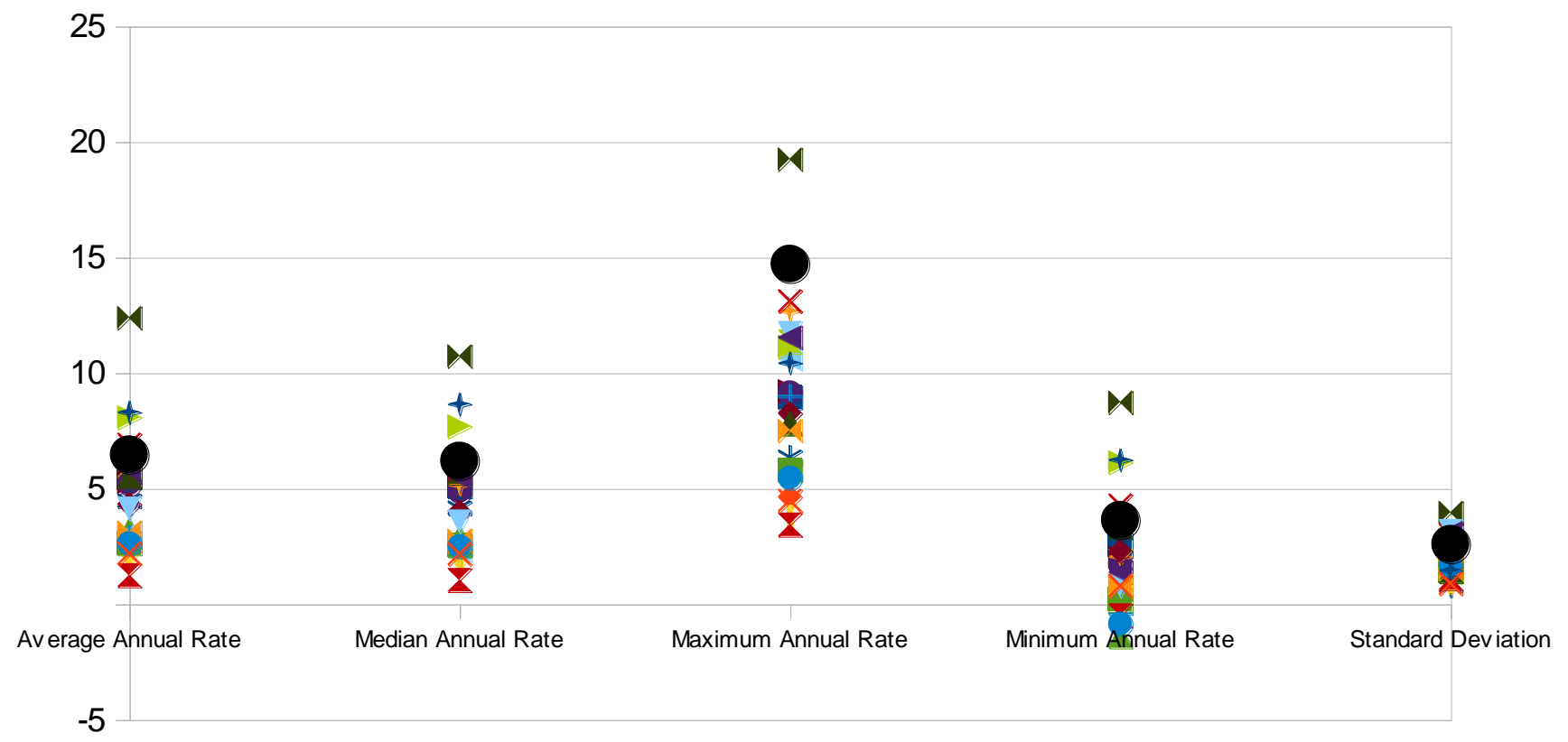

Figure 2. Inflation Rates for ITR Countries for the Period in which each Country was under Full ITR

Source: Elaborated by the authors using the figures of IMF (2018a) and World Bank (2018).

Comparing with the BRICS (not shown on figures), Brazil has the third lowest (or third highest, since there are only 5 countries in the group) average and minimum inflation rate, the second highest median, maximum, and variable inflation rate. Russia is the worst in the group. This means that countries more or less similar to Brazil in terms of their level of development can have lower and more stable inflation rates without formally adopting an ITR or any other tight monetary policy scheme. China is the single most effective country in stabilizing prices in the group, much better by any standard than full ITR countries like Brazil and South Africa.

Considering group 3 (not shown as well), Brazil has the lowest average and median inflation in the group. It has the third highest maximum (or the third lowest) annual inflation rate for the period considered, the lowest minimum annual inflation rate and the second lowest standard deviation. However, it is difficult to state positively that those other countries would be better if they had adopted an ITR.

In terms of interest rates, Brazil has the highest average, median, and maximum nominal interest for all three groups. Figure 3 shows the statistics for the ITR group only. It has the third highest minimum annual nominal interest rate and volatility. Figure 4 illustrates the combination of nominal interest rates and actual or ex post inflation rates for the full sample. Brazil (big black circle) is way off the mark regarding nominal interest rates. As discussed above, since Brazil does not have the highest absolute inflation rate as a justification for the abnormally high interest rate, neither among 
the ITR countries, nor among the BRICS, or the interest-caused-welfare loss countries. Thus, the highest average, median, and maximum nominal interest rates for the entire period must have another explanation.

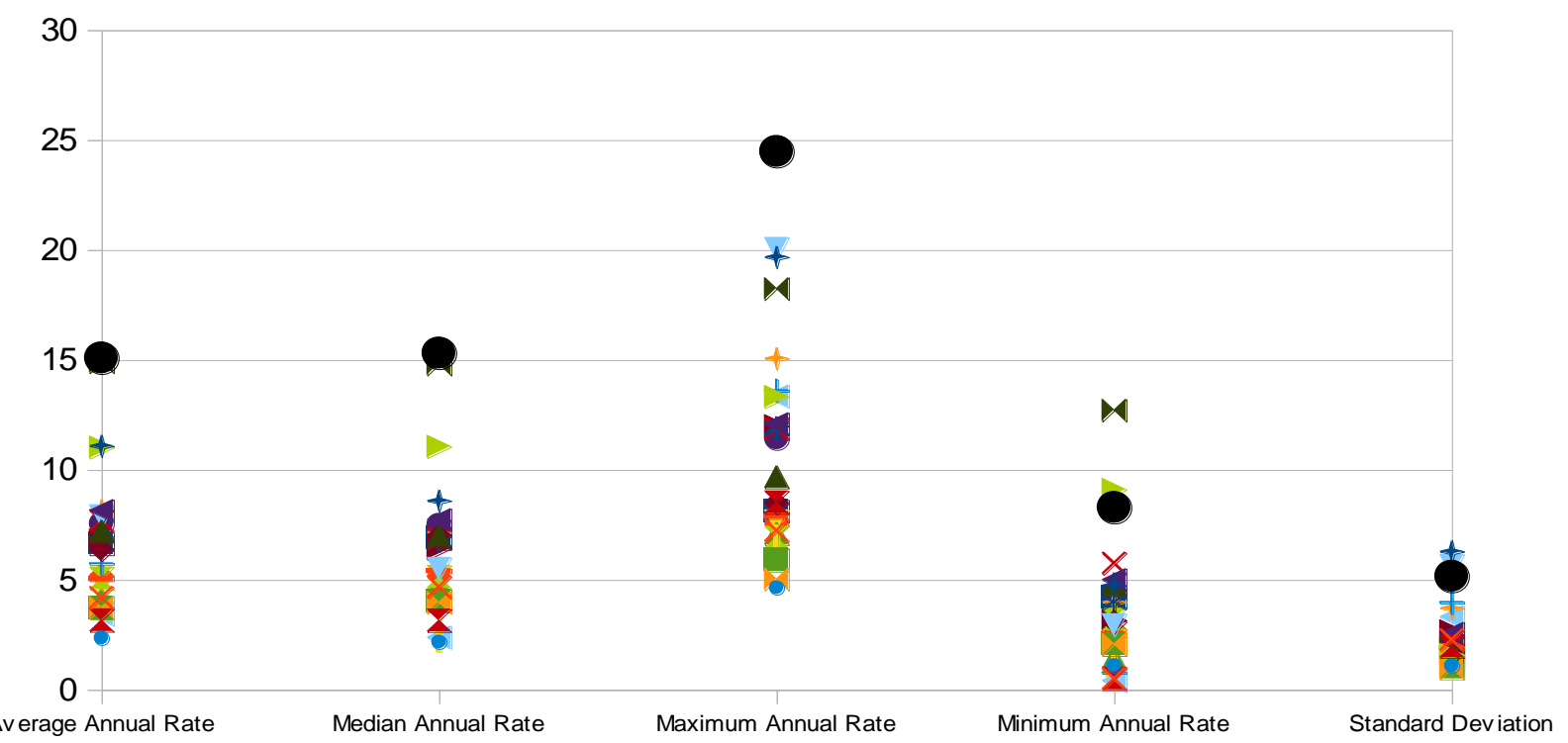

Figure 3. Nominal Interest Rate Policies for ITR Countries for the Period in which each Country was under Full ITR Source: Elaborated by the authors using the figures of IMF (2018a) and World Bank (2018).

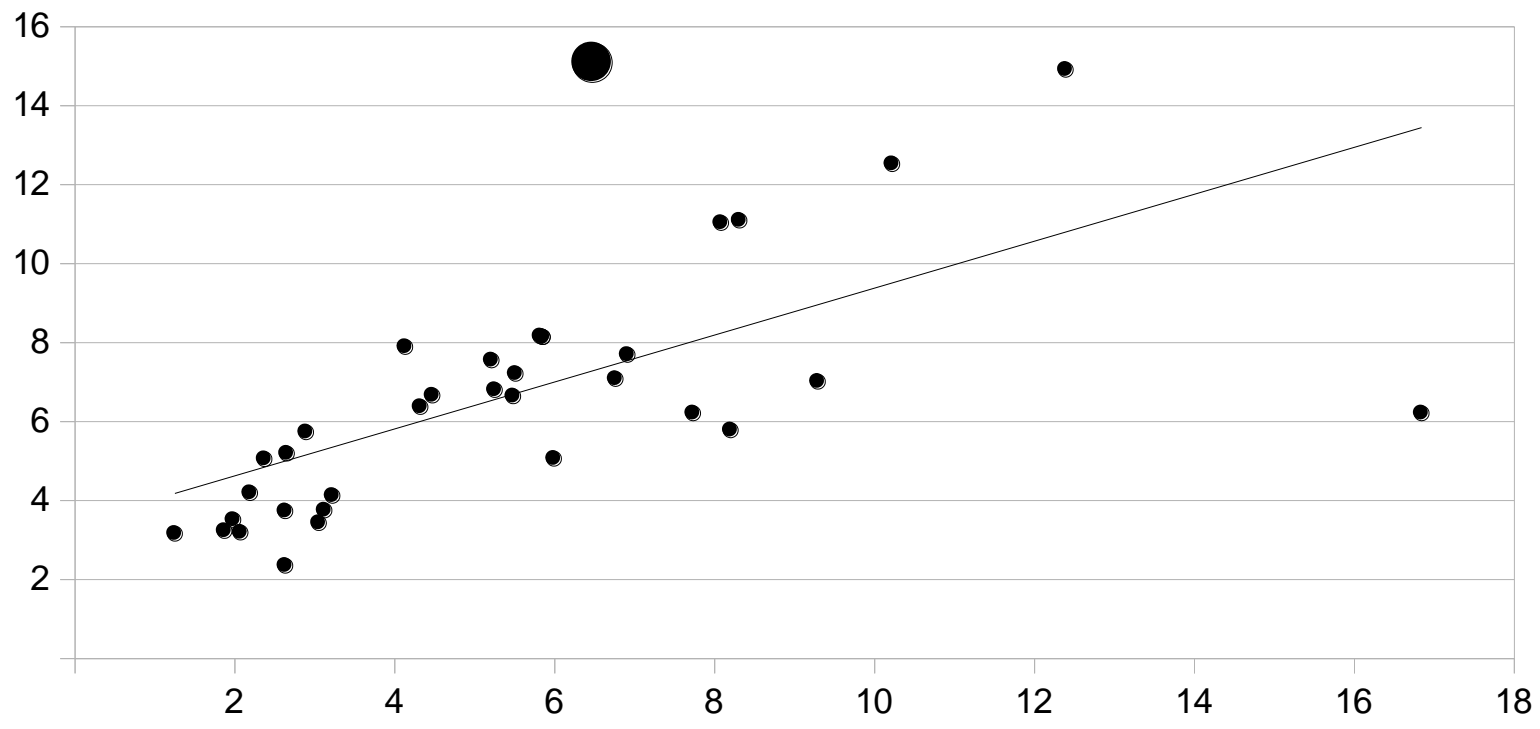

Figure 4. Nominal Interest Rates (vertical axis) and Inflation Rates for the Full Sample (ITR Countries, BRICS, and Interest Rate Champions)

Source: Elaborated by the authors using the figures of IMF (2018a) and World Bank (2018).

In this regard, we also identified countries from all 3 groups with episodes of hyperinflation, according to Syklos (1995) and IMF (2018b), in the twentieth or twenty-first centuries as a subgroup (Armenia, Brazil, Chile, China, Hungary, Nicaragua, Peru, Poland, and Russia). All other countries have lower interest rates than Brazil, meaning that having had hyperinflation in the past might not explain higher current interest rates (preventative measure to avoid risking hyperinflation again, for example). The same conclusion regarding high nominal interest rates is valid for another subgroup with countries that experienced default or restructuring of their central government debts at some point in the twentieth or twenty-first century, according to Reinhart \& Rogoff (2008) ${ }^{7}$ (Brazil, China, Ghana, Mexico, Peru, Romania, and Russia). Assuming hypothetically that they all have a permanently high risk of default based only on their

${ }^{7}$ Given the recent discussion about their flawed methods of investigation (Herndon, Ash \& Pollin, 2014), it is advisable to view their data with a grain of salt. 
past behavior, this fact alone still cannot explain the Brazilian anomaly. A combination of hyperinflation and debt problems does not seem to change the picture either.

As a result of the high nominal interest rates, Brazil has the higher average and median real interest rate for all three groups, with many countries showing even negative averages and medians (Figure 5). Regarding group 1, Brazil has also the highest maximum real interest rate, again showing that the ITR is flawed as a tool to fight inflation in Brazil. It is astonishing to see that it keeps a positive minimum real interest rate whereas most countries in the three groups have negative rates for the minimum. In terms of volatility, unlike inflation, Brazil performs well only regarding groups 2 and 3. This means that, since average real rates are high, rentiers have a stable and reliable source of real income in Brazil.

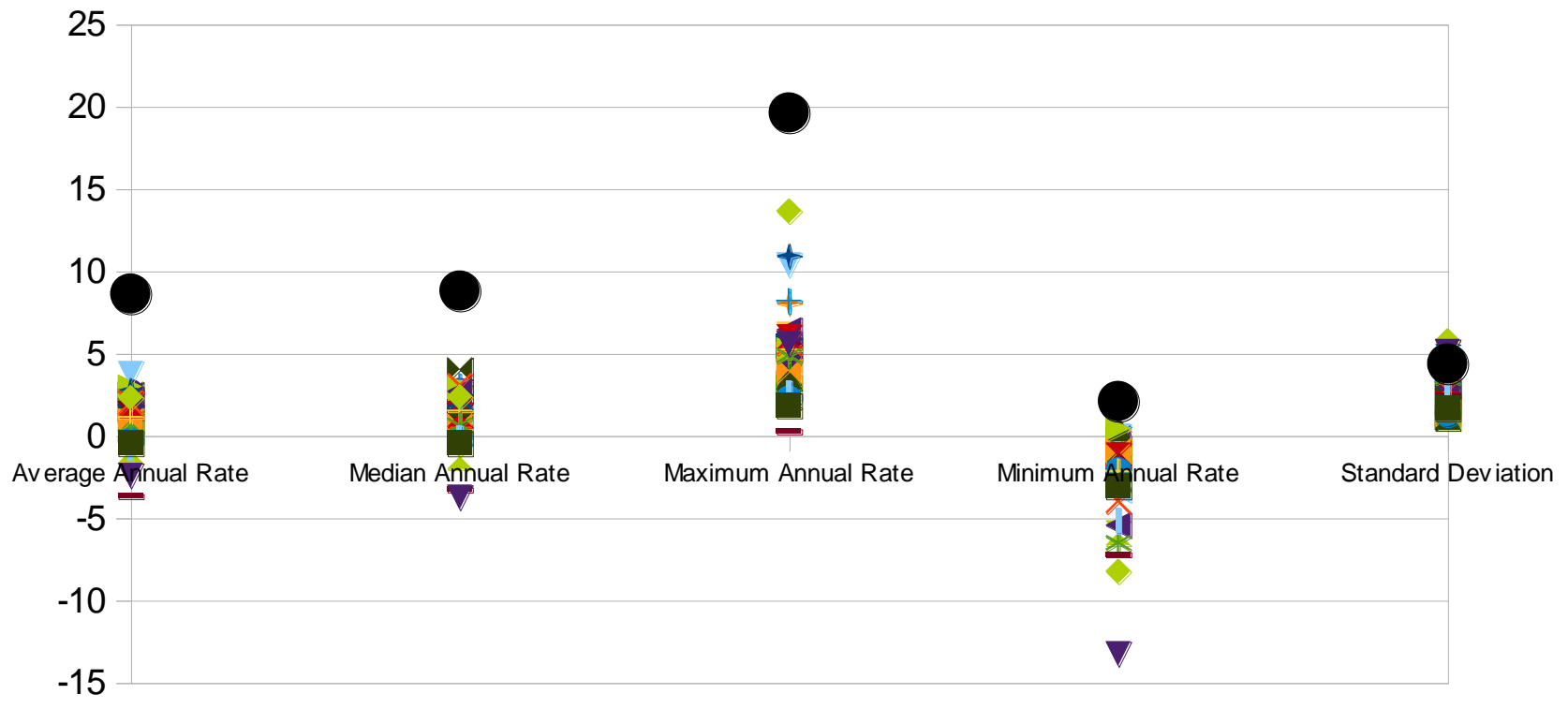

Figure 5. Real Interest Rates for the Full Sample (ITR Countries, BRICS, and Interest Rate Champions)

Source: Elaborated by the authors using the figures of IMF (2018a) and World Bank (2018).

Brazil fares slightly better regarding unemployment rates (not shown), although it has the second highest average and median unemployment rates within groups 2 and 3. This is probably because of the center-left political coalition that has ruled Brazil from 2003 until the Parliamentary Coup of 2016, ${ }^{8}$ which tended to favor, on average, pro-labor policies. Regarding the maximum and minimum unemployment rates, it ranks either the second or the third in these groups. It has a better situation regarding many other ITR countries, but there are countries that target inflation and yet present lower unemployment rates. So, as far as the narrow official measures of unemployment are concerned, they were relatively lower despite the modest rates of output growth. But broad measures show a high level of labor idleness or underemployment in Brazil.

Regarding real GDP growth rates, Brazil has the second lowest average and median rates in group 3, and the lowest average and median regarding group 2. And in group 1 there are many countries with faster economic growth. Regarding the minimum rates, Brazil is right in the middle. Volatility has not been a remarkable characteristic of the Brazilian growth over the ITR period, meaning stable and modest rates. Figure 6 presents the results for all groups.

\footnotetext{
${ }^{8}$ See Santos and Guarnieri (2016) for a discussion.
} 


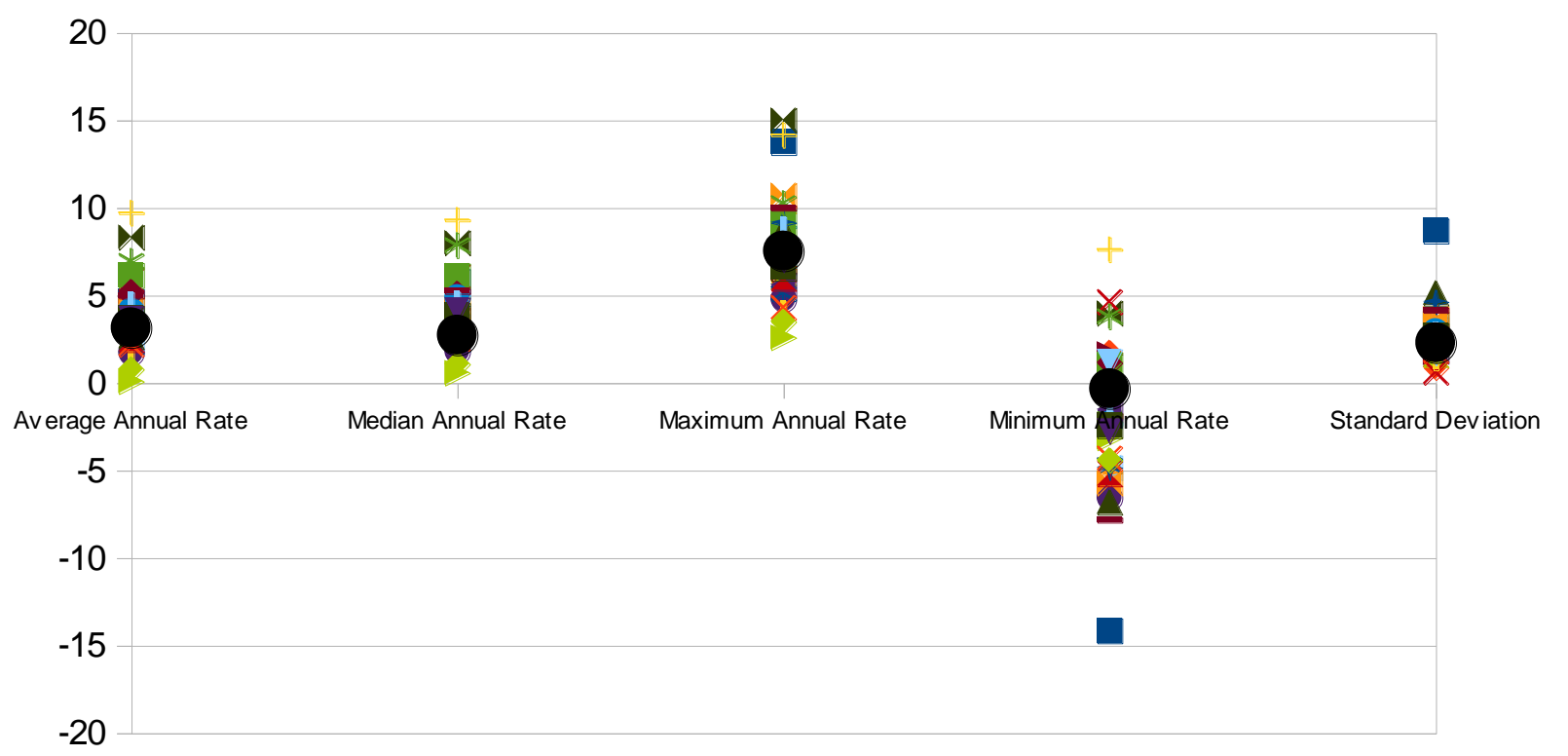

Figure 6. Real GDP Growth Rates for the Full Sample (ITR Countries, BRICS, and Interest Rate Champions)

Source: Elaborated by the authors using the figures of IMF (2018a) and World Bank (2018).

In conclusion, the international comparison with different groups of countries, the criterion adopted here to justify evaluating the levels of interest rates as low, normal, or high, strongly suggests that the ITR has not been working in Brazil as expected by NMC supporters, and therefore the monetary policy has been ineffective, with the undesirable consequence of sustaining excessive real interest rates because inflation, being mostly cost-push, does not respond directly to interest-related expenditures, and not very low unemployment rates (mainly considering the broad measures that take into account the part-time jobs and underemployment). As far as the average international experience with interest and inflation rates can be considered a 'norm', Brazil has not had a "normal" monetary policy management under the ITR. As a consequence, GDP growth has also been sub-par, but with no major consequences to price level dynamics. The next section considers a few additional remarks about that experience.

\section{Monetary Policy Ineffectiveness and Rentier'S Interests in Brazil: The Expected Inflation Trap}

Are there any other likely explanations for the high real interest rates in Brazil, besides the ones discussed in section 2 ? Dutt (1990-1991) argues, from a theoretical perspective, that higher nominal interest rates in LDC will reduce inflation - by hiking real interest rates concomitantly - only when capacity utilization is full. This requires, from an empirical standpoint, a different set of statistics rather than the ones considered above. However, a different question concerns the level of interest rates necessary to bring inflation down under full capacity. Why would Brazil be required to have nominal interest rates well above most of the other countries in the sample in order to be able to achieve lower and more stable inflation rates? If one follows Dutt (1990-1991), Brazil must have a large amount of idle capacity, since high interest rates are abnormally high. For the same reason, since average growth rates have been modest, than some idle capacity is likely to be taking place in Brazil, but not to the point of compensating for the skyhigh interest rates. Therefore, there are high interest rates, relatively high inflation rates, and some unused capacity due to other factors.

A more plausible explanation, in our view, is espoused by some structuralist authors. According to Bresser-Pereira \& Gomes (2009), the interest rate is very high in Brazil due to an interest/exchange rate trap, while Arestis, Ferrari Filho \& Paula (2011) argue that the Selic is high because the BCB was 'captured' by rentiers. ${ }^{9}$ So, the ITR is not necessarily the only culprit for the high interest rates in Brazil, since the phenomenon is at least three decades old according to the authors. The ITR could be seen as the newest achievement of rentiers interests, which in our view also includes the

\footnotetext{
${ }^{9}$ Smithin (1996: 5) equally claims that "[t]he result [of negative real rates of interest] was ultimately a political revolution around the years 1979 to 1982, the most important feature of which was the 'capture' of central banks by rentier interests, and their conversion thereafter to exclusively 'hard money', high interest, and anti-inflation policies. This was the 'Revenge of the Rentiers"'. This means that the overall setting is pretty much the same in most of the Western World, but the way that rentiers control and influence monetary policy differs among countries, as it is argued below.
} 
financial sector, to maintain their high interest earnings. By the same token, Vernengo (2008), analyzing the very first years of the ITR in Brazil, argues that the distributive conflict is important for the inflationary dynamics, and that indeed the monetary policy regime favors the financial sector interests within the rentier segment.

But how rentiers are able to shape monetary policy in Brazil in a way unseen in other countries and for such a long time? Why are they extraordinarily powerful in setting such successful interest-income transfer program? Samuels (2001) show that banks have been among the most important contributors to finance political campaigns in Brazil. Nevertheless, under supposedly operationally autonomous central banks, this link between financial interests, politics, and monetary policy would be more opaque. We reject this type of explanation, since there is no need to keep bribing politicians if the rentiers have control over central banks and politicians no longer have such power (which is questionable in Brazil). It may be argued that rentier interests have been shaping the conduct of monetary policy since the military-corporate dictatorship from the 1960s to the 1980s. And bankers also bribe politicians in other countries that have lower interest rates than Brazil. So, the explanation lies elsewhere.

The relationship between autonomous central banks, monetary policy, and fiscal policy, mainly public debt, is better understood by the financialization literature. Bruno et al. (2011) show that the public debt, and the corresponding interest payments, is a major source of financialized capital accumulation in Brazil. It is possible to argue, based on this reasoning, that nonfinancial firms are also earning interest payments and are not opposed to high interest rates, being part of the rentier segment. But are they able to set the monetary policy agenda? We do not think so.

Therefore, in our view, the influence of rentiers over monetary policy in Brazil, a very likely explanation for the stubbornly high interest rates, has more to do with an institutional setting in which central banks are structurally constrained to keep nominal and real interest rates high, but in Brazil this framework has favored the rentier class on an unseen scale, with the result that monetary policy is ineffective in reducing and stabilizing inflation rates to the international average levels, but very effective in transferring income to rentiers. The BCB sets the short-term interest rate based on a survey of expected inflation mostly by financial institutions. Many issues seem to affect those expectations. For instance, despite the fact that the central government has never defaulted on its domestic debt, financial institutions seems to assume that the risk of default is permanently high, and therefore the interest rates must be kept at high levels in order to finance government deficits. This is an example of expectational trap.

The rentiers also seem to assume that monetary policy has not been credible, and expected inflation is rigid on the upper levels, even when actual inflation slightly falls. The solution is therefore to jack interest rates up even more. Inflation does not fall fast enough? Jack up one more time. If interest rates do not drop it is because inflationary expectations are rigid due to the lack of true commitment with lower inflation rates. That is, a possible interpretation of rentiers power over monetary policy is that inflation rates do not fall in Brazil because expected inflation by financial firms, whose services have a small participation in the headline CPI, are rigid, and they are rigid because interest rates are kept unduly low, even though they are among the highest one in the world. Interest rates, according to rentiers in general and financial firms in particular, only reflect the lack of credibility of monetary policy, and they are the only ones capable of defining what is credible and what is not. Credibility is defined as what financial firms think it is or, in our interpretation, whatever policies favor financial interests. If financial firms do not accept a policy, it is not credible by definition (Grabel, 2003).

Therefore, a consequence of their likely view, and that it is not espoused by this article as argued before, is that expected inflation fully determines actual inflation rates, and the former do not fall because real interest rates are not high enough. But since interest rates also measure the rate at which capitalized monetary and financial wealth grows, it is our argument that and rigid expected inflation rates have a major consequence in the form of transfer of funds from the government to the rentiers whose expectations anchor the policy decisions by the BCB. So, it is highly convenient to have expectations disconnected from actual rates of inflation. Paraphrasing Kalecki, rentiers in Brazil earn what they expect to earn. It would certainly be outrageous for orthodox economists, mainly the ones working for the rentiers, if a rule of wage-setting was established such that nominal wages were automatically adjusted based on the workers and trade unions own inflationary expectations, surveyed by the BCB. But that is exactly what rentiers have accomplished themselves in Brazil. Thus, the expectations of rentiers seem to have transformed the ITR into an expectational trap, a powerful mechanism to sustain high interest rates (and earnings) in Brazil even though it has not had significant impacts on actual inflation rates, since they are not sensitive to credit-financed demand.

Exhibit 1, below, proposes a tentative theoretical classification for the different combinations of nominal interest and actual inflation rates as a way to interpret the structure of monetary policy. The abnormal power of rentiers in Brazil in setting the monetary policy makes it hard to classify the country using this scheme, however, since interest rates in Brazil are very high, but the inflation rates are not low for international standards (although they are not higher than the ones prevailing in many countries in our sample). The recent episode in Brazil, when public banks were enticed to boost competition and reduce market interest rates, along with policy rates reductions by the $\mathrm{BCB}$, is telling in this respect. It 
led to all types of financial "revolts" in the Brazilian press, including the financialized industrialists. This episode deserves a deeper treatment that is beyond the scope of this article, since it raises the question of why and how the attempt at monetary policy change failed, and the potential role that rentiers' interests played in it besides the public opinion channel.

Inflation Rate

$\mathrm{L}$

$\mathrm{H}$

\begin{tabular}{|c|l|l|}
\cline { 2 - 3 } \multicolumn{1}{c|}{$\mathrm{H}$} & $\begin{array}{l}\text { Rentiers' } \\
\text { party/ineffective } \\
\text { monetary policy }\end{array}$ & $\begin{array}{l}\text { Rentiers potentially } \\
\text { subdued/potentially } \\
\text { effective policy }\end{array}$ \\
\cline { 2 - 3 } $\mathrm{L}$ & $\begin{array}{l}\text { Rentiers potentially } \\
\text { subdued/ potentially } \\
\text { effective policy }\end{array}$ & $\begin{array}{l}\text { Rentiers' } \\
\text { hell/inefective } \\
\text { monetary policy }\end{array}$ \\
\hline
\end{tabular}

Exhibit 1 . A typology of monetary policy regimes $(\mathrm{L}=\mathrm{Low}, \mathrm{H}=$ high $)$

Source: Elaborated by the authors.

Yet, the Brazilian anomaly of an expectational trap seems more close to a case of rentiers' party, with excessive real interest rates based not on low inflation, but instead on exorbitant nominal interest rates, whereas other countries seem to have managed to subdue rentiers' interests, for some reasons that must be addressed by additional research, with nominal interest rates closer to the inflation rates and therefore closer to Smithin's Rule of zero real interest rate (Smithin, 1996). Russia, on the other hand, would be an example of rentiers' hell, with relatively low nominal interest rates and very high inflation rates.

Therefore, it is hard to defend ITR in Brazil as effective in achieving its stated goals. Considering the international standpoint, real interest rates have been excessive on several grounds, despite a fall during the center-left government (that has not led to uncontrolled inflation, as predicted by the NCM defenders), but not enough to bring it down to the international average. This requires a specific definition of this phenomenon. Conservative scholars and economists, rentiers, and international financial institutions, when dealing with budget deficits, frequently label the government as irresponsible and the corresponding excessive spending levels as profligate and wasteful (Cardoso \& Helwege, 1991; Altman \& Haass, 2010). If this is the case, the same seems to be applicable to monetary policy in Brazil, mainly regarding, but not exclusively, the ITR. Using the same criterion, the $\mathrm{BCB}$ should be labeled irresponsible for maintaining very high nominal and real interest rates, with no trivial burdens on the nominal budget deficits (Weisbrot et al., 2017). In this case, the fiscal "irresponsibility" is more likely a side effect of an 'irresponsible' monetary policy. This policy is wasteful regarding GDP growth and decent employment policies when compared to other countries, although it is still profligate regarding the rentiers' interests well served by this very monetary framework of unnecessary transfers from taxpayers.

\section{Conclusion}

The descriptive statistics and the discussion presented in the sections above suggest that the ITR in Brazil does not seem to be effective in fulfilling its official objectives of keeping low and stable inflation and contributing to higher growth rates and low unemployment, as expected by its NMC supporters. The ITR in Brazil has not managed to achieve low and stable inflation rates, despite having one of the highest average nominal and real interest rates. This is valid both in terms of ITR evolution in Brazil as well as in comparison with other countries, both fully-fledged ITR or not, and for countries with experiences of hyperinflation and domestic debt default or restructuring or a combination of both. If the international experience can be considered a valid basis for comparison, despite all national and regional economic heterogeneity, monetary policy in Brazil has been very likely abnormal. If one adopts a zero real rate goal $\grave{a}$ la Smithin (1996) as a proper level for guiding nominal interest rate setting, Brazil has had a stubbornly excessive real 
interest rate. This rate does not reduce inflation because there is no excess of credit-funded demand, but cost-push inflation, and as a consequence the country has excess transfer payments in the form of nominal budget deficits to the rentiers because they earn what they expect to earn in the current monetary framework.

That is, the policy regime seems to be monetarily ineffective, irresponsible, and wasteful. Inflation seems to have different determinants, including external transmissions, distributive conflicts, and supply shocks. In this case, a demand management policy of keeping one of the highest real interest rates in the world is ineffective and simply represents an income transfers policy, since it is set above and beyond what is needed in other countries for dealing with similar macroeconomic imbalances. That is, we argue that the single most important instrument for keeping excessive real interest rates in Brazil is the expectations trap that frame the monetary policy, in which the $\mathrm{BCB}$ overemphasizes the inflationary expectations of rentiers for defining interest rates, given them a power over monetary policy not likely to be seen in other countries.

Although the goal of this preliminary study is not to provide policy prescriptions, and keeping in mind that more meaningful research is always needed when practical matters are involved, if Brazil aims at achieving price stability, low unemployment, and higher and sustainable growth rates, the ITR does not seem to have been the answer. An alternative along the lines of a rule of parking the interest rates (Rochon \& Setterfield, 2008) is therefore necessary, for the sake of reducing inflation, boosting real GDP and employment growth, and minimizing income and wealth concentration. And parking it at the levels consistent with Smithin's Rule is one possible bet. And this is likely to be met with strong resistance from rentiers' interests and their allies in the media and academia.

\section{References}

Altman, R. C., \& Haass, R. N. (2010). American profligacy and American power: The consequences of fiscal irresponsibility. Foreign Affairs, 89(6), November/December, 25-34.

Arestis, P., \& Sawyer, M. (2008). New consensus macroeconomics and inflation targeting: Keynesian critique. Economia $e \quad$ Sociedade, $17 \quad$ (número especial), Dezembro, 631-655. https://doi.org/10.1590/S0104-06182008000400006

Arestis, P., Ferrari Filho, F., \& Paula, L. F. (2011). Inflation targeting in Brazil. International Review of Applied Economics, 25(2), 127-148. https://doi.org/10.1080/02692171.2010.483465

Asensio, A. (2012). Between the cup and the lip: On Post Keynesian interest rate rules and long-term interest management. In L. P. Rochon, L. P., \& S. Y. Olawoye, S. Y. (Eds.), Monetary Policy and Central Banking: New Directions in Post-Keynesian Theory (pp.3-20). Cheltenham, UK: Edward Elgar.

Ball, L. (2011). Money, Banking and Financial Markets. New York, NY: Worth Publishers.

Ball, L., \& Sheridan, N. (2003). Does inflation targeting matter? NBER Working Paper 9577.

Barro, R., \& Sala-i-Martin, X. (1990). World real interest rates. NBER Macroeconomics Annual, Volume 5. https://doi.org/10.1086/654127

Blanchard, O., \& Gali, J. (2005). Real wage rigidities and the New Keynesian model. NBER Working Paper 11816. https://doi.org/10.3386/w11806

Borio, C. E. V., \& Filardo, A. (2007). Globalisation and inflation: New cross-country evidence on the global determinants of domestic inflation. BIS Working Papers 227. https://doi.org/10.2139/ssrn.1013577

Brazilian Central Bank (BCB) (2016). Sistema de Expectativas de Mercado (Market Expectations System). Retrieved from http://www.bcb.gov.br/conteudo/home-ptbr/FAQs/FAQ\%2013-Expectativas\%20de\%20Mercado.pdf. Accessed on Sptember 24, 2018.

Brazilian Central Bank (BCB) (2018). Séries Temporais. Retrieved from http://www.bcb.gov.br. Accessed on September 24, 2018

Bresser-Pereira, L. C., \& Gomes, C. (2009). Inflation targeting in Brazil: A Keynesian approach. In L.R. Wray, L.R., \& M. Forstater (Eds.), Keynes and Macroeconomics After 70 Years: Critical Assessments of the General Theory (pp.176-195). Cheltenham, UK: Edward Elgar.

Bruno, M., Diawara, H., Araújo, E., Reis, A. C., \& Rubens, M. (2011). Finance-led growth regime no Brasil: estatuto teórico, evidências empíricas e consequências macroeconômicas. Revista de Economia Política, 31(5), 730-750. https://doi.org/10.1590/S0101-31572011000500003

Caldentey, E. P., \& Vernengo, M. (2013). Is Inflation targeting operative in an open economy setting? Working Papers 324/Political Economy Research Institute, University of Massachusetts at Amherst.

Cardoso, E., \& Helwege, A. (1991). Populism, profligacy, and redistribution. In D. Rudiger D., \& S. Edwards (Eds.), 
The Macroeconomics of Populism in Latin America (45-74). Chicago, IL: University of Chicago Press.

Carlin, W., \& Soskice, D. (2006). Macroeconomics: Imperfections, Institutions and Policies. Oxford, UK: Oxford University Press.

Drumond, C .E. I., \& Porcile, G. (2012). Inflation targeting in a developing economy: policy rules, growth, and stability. Journal of Post Keynesian Economics, 35(1), 137-162. https://doi.org/10.2753/PKE0160-3477350108

Dutt, A. K. (1990-1991). Interest rate policy in LDCs: A Post Keynesian view. Journal of Post Keynesian Economics, 13(2), Winter, 210-232. https://doi.org/10.1080/01603477.1990.11489842

Epstein, G. A., \& Yeldan, E. (2009). Beyond Inflation Targeting: Assessing the Impacts and Policy Alternatives. Cheltenham, UK: Edward Elgar. https://doi.org/10.4337/9781849801980

Ferrari, F. F., \& Milan, M. (2018). Liquidity Trap: The Brazilian version. Brazilian Keynesian Review, forthcoming.

Ferrari, F. F., \& Schifino, L. A. (2010). Performance macroeconômica sob o regime de metas de inflação: uma análise para alguns países emergentes selecionados. Análise Econômica, 28(54), Setembro, 117-140.

Grabel, I. (2003). Ideology, power and the rise of independent monetary institutions in emerging economies. In J. Kirshner. (Ed.), Monetary Orders: Ambiguous Economics, Ubiquitous Politics (25-54). Ithaca, NY: Cornell University Press.

Hammond, G. (2012). State of the art of inflation targeting. Bank of England/CCBS Handbook \# 29, February.

Hanke, S. (2014). Measuring Misery around the World. Retrieved from https://www.cato.org/publications/commentary/measuring-misery-around-world. Accessed on September 24, 2018.

Herndon, T., Ash, M., \& Pollin, R. (2014). Does high public debt consistently stifle economic growth? A critique of Reinhart and Rogoff. Cambridge Journal of Economics, 38(2), 257-279. https://doi.org/10.1093/cje/bet075

IMF (2018a). Data and Statistics. Retrieved from http://www.imf.org. Accessed on September 24, 2018.

IMF (2018b). World Economic OutLook/Several Years. Retrieved from http://www.imf.org. Accessed on September 24, 2018.

IPEADATA (2018). Séries Históricas. Retrieved from http://www.ipeadata.gov.br. Accessed on September 24, 2018.

Libanio, G. (2010). A note on inflation targeting and economic growth in Brazil. Revista de Economia Política, 30, 73-88. https://doi.org/10.1590/S0101-31572010000100005

Lima, G. T., \& Setterfield, M. (2008). Inflation targeting and macroeconomic stability in a Post Keynesian economy. Journal of Post Keynesian Economics, 30(3), Spring, 435-461. https://doi.org/10.2753/PKE0160-3477300307

Marconi, N., \& Rocha, M. (2012). Exchange rate, foreign trade and early deindustrialisation: the case of Brazil. Economia \& Sociedade, 21 (número especial), 853-888. https://doi.org/10.1590/S0104-06182012000400007

Modenesi, A., \& Araújo, E. C. (2013). Price stability under inflation targeting in Brazil: an empirical analysis of the monetary policy transmission mechanism based on a VAR model (2000-2008). Investigación Económica, LXXII (283), 99-133. https://doi.org/10.1016/S0185-1667(13)72588-8

Reinhart, C., \& Rogoff, K. (2008). The forgotten history of the domestic debt. NBER Working Paper 13.946. https://doi.org/10.3386/w13946

Rochon, L. P., \& Setterfield, M. (2008). The political economy of interest rate setting, inflation, and income distribution. International Journal of Political Economy, 37(2), 5-25. https://doi.org/10.2753/IJP0891-1916370201

Rousseas, S. (1985). A markup theory of bank loan rates. Journal of Post Keynesian Economics, 8(1), Autumn, 135-144. https://doi.org/10.1080/01603477.1985.11489549

Samuels, D. (2001). Money, elections, and democracy in Brazil. Latin America Politics and Society, 43(2), 27-48. https://doi.org/10.1111/j.1548-2456.2001.tb00398.x

Santos, A. L. M. (2011). Inflation targeting in a Post Keynesian economy. Journal of Post Keynesian Economics, 34(2), 295-318. https://doi.org/10.2753/PKE0160-3477340206

Santos, F., \& Guarnieri, F. (2016). From protest to parliamentary coup: An overview of Brazil's recent history. Journal of Latin America Cultural Studies, 25(4), 485-494. https://doi.org/10.1080/13569325.2016.1230940

Séries Temporais. (2018). Retrieved from http://www.bcb.gov.br. Accessed on September 24, 2018.

Setterfield, M. (2006). Is inflation targeting compatible with Post Keynesian economics? Journal of Post Keynesian Economics, 28(4), 653-671. https://doi.org/10.2753/PKE0160-3477280407 
Smithin, J. (1996). Macroeconomic Policy and the Future of Capitalism. The Revenge of the Rentiers and the Threat to Prosperity. Cheltenham, UK: Edward Elgar.

Smithin, J. (2007). A real interest rate rule for monetary policy? Journal of Post Keynesian Economics, 30(1), 101-118. https://doi.org/10.2753/PKE0160-3477300105

Summa, R., \& Serrano, F. (2015). Distribution and cost-push inflation in Brazil under inflation targeting, 1999-2014. Retrieved from https://franklinserrano.files.wordpress.com/2015/07/summa-serrano-22-july-2015-distribution-and-cost-push-inflat ion-in-brazil-under-inflation-targeting-1999-20141.pdf. Accessed on September 24, 2018.

Syklos, P. (1995). Great Inflations of the 20th Century: Theories, Policies, and Evidence. Aldershot, UK: Edward Elgar.

Vernengo, M. (2008). The political economy of monetary institutions in Brazil: The limits of the inflation-targeting strategy, 1999-2005. Review of Political Economy, 20(1), 95-110. https://doi.org/10.1080/09538250701661863

Weisbrot, M., Johnston, J., Carrillo, J. V., \& Mello, V. (2017). Brazil's enormous interest rate tax: Can Brazilians afford it? CEPR, April. Retrieved from http://cepr.net/images/stories/reports/brazil-interest-rates-2017-04.pdf. Accessed on September, 2018.

World Bank. (2018). Indicators. Retrieved from https://data.worldbank.org/indicator. Accessed on September 24, 2018.

\section{Copyrights}

Copyright for this article is retained by the author(s), with first publication rights granted to the journal.

This is an open-access article distributed under the terms and conditions of the Creative Commons Attribution license which permits unrestricted use, distribution, and reproduction in any medium, provided the original work is properly cited. 